
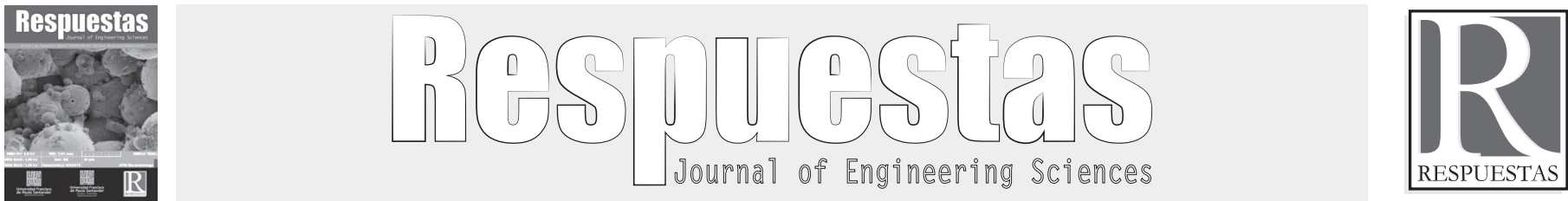

Review Article

https://doi.org/10.22463/0122820X.1742

\title{
Conceptual framework for watershed management based on the systematization of the pilot project for Colombia of the Pamplonita river basin
}

\author{
Marco conceptual para ordenación de cuencas a partir de la sistematización del proyecto piloto para Colombia \\ de la cuenca del río Pamplonita
}

\author{
Yenni Esperanza Rodríguez-Pérez ${ }^{1 *}$, Jacipt Alexander Ramón-Valencia² ${ }^{2}$ John Hermógenes Suárez-Gélvez ${ }^{3}$ \\ ${ }^{1 *}$ Magister en Ingeniería Ambiental, yenniesperanzarp@ufps.edu.co, Orcid: 0000-0002-2695-5513, Universidad Francisco de Paula Santander, Cúcuta, Colombia. \\ 2Doctor en Ingeniería Química, Ambiental y de Procesos, jacipt@unipamplona.edu.co, Orcid: 0000-0002-2030-4904, Universidad de Pamplona, Pamplona, \\ Colombia. \\ ${ }^{3}$ Magister en Ingenieria Sanitaria y Ambiental, johnhermogenessg@ufps.edu.co, Orcid: 0000-0002-9121-0630, Universidad Francisco de Paula Santander, \\ Cúcuta, Colombia.
}

How to cite: Y.E. Rodríguez-Pérez, J.A. Ramón-Valencia, J.H. Suárez-Gélvez, “Conceptual framework for watershed management based on the systematization of the pilot project for Colombia of the Pamplonita river basin", Respuestas, vol. 23, no. 2, pp. 96$109,2018$.

Received on February 10, 2018 - Approved on June 01, 2018.

\begin{tabular}{ll}
\hline Keywords: & $\begin{array}{l}\text { Since the issuance of Decree } 1729 \text { of 2002, the need for the management of watersheds and the concepts, } \\
\text { objectives and scope of the corresponding management plans in the country was established. The final } \\
\text { purpose of this exercise is to define and logically and coherently link the key concepts and variables } \\
\text { Hydrographic } \\
\text { basin, conceptual } \\
\text { framework, } \\
\text { management, } \\
\text { the state of the art and determine future research needs. For its elaboration a recognition of the literature } \\
\text { concerning the topic was carried out, an evaluation and follow-up of the progress reports delivered by each } \\
\text { oxstematization of } \\
\text { of the components, the conclusions that came out as a result of the weekly work tables of the technical and } \\
\text { administrative teams, the design and reading of a format applied during the systematization of the experience, } \\
\text { and the technical analysis of the guide for the river basin development and management plans. A conceptual } \\
\text { framework was constructed with the terms of greatest importance to be managed by a team that participates } \\
\text { in management processes during the various phases of a study. A clear conceptual framework allows to } \\
\text { guide the research, provides a review to decipher and understand the results of the study and facilitates } \\
\text { the production of new knowledge and the articulation between the technical teams for the fulfillment of } \\
\text { the objectives during the development of river basin management plans (POMCA). Taking as a reference, } \\
\text { the experiences lived during the execution of this study, it can be said that it is fundamental that in the } \\
\text { preparation and during the beginning of the diagnosis, professionals hold conceptualization meetings so that } \\
\text { the different products to be obtained show a joint participation from the different knowledge groups. }\end{array}$
\end{tabular}

\section{RESUMEN}

Palabras clave:

Cuenca

hidrográfica, marco conceptual, ordenación, POMCA y sistematización de experiencias.
A partir de la expedición del Decreto 1729 de 2002, se estableció la necesidad de la ordenación de las cuencas y los conceptos, objetivos e importancia de los planes de manejo correspondientes en el país. El propósito final de éste ejercicio es definir y vincular lógica y coherentemente los conceptos claves y variables necesarios para abordar investigaciones focalizadas en la ordenación y administración de cuencas hidrográficas. Además, verificar el estado del arte y determinar las necesidades investigativas futuras. Para su elaboración se llevó a cabo un reconocimiento de la literatura concerniente al tema, una evaluación y seguimiento de los informes de avance entregados por cada uno de los componentes, las conclusiones que salieron como resultado de las mesas de trabajo semanal del equipo técnico y administrativo, el diseño y lectura de un formato aplicado durante la sistematización de la experiencia, y el análisis de la guía técnica

*Corresponding author.

E-mail address: yenniesperanzarp@ufps.edu.co (Yenni Esperanza Rodríguez-Pérez)

(c) (1) $\odot$ Peer review is the responsibility of the Universidad Francisco de Paula Santander

cc) This is an article under the license CC BY-ND (http://creativecommons.org/licenses/by-nc-nd/4.0/). 
para la formulación de los planes de ordenación y manejo de cuencas hidrográficas. Se construyó un marco conceptual con los términos de mayor importancia para ser manejados por un equipo que participe en procesos de ordenación en el transcurso de las diversas fases de un estudio. Un marco conceptual claro permite orientar la investigación, brinda una reseña para descifrar y comprender los resultados del estudio y facilita la producción de nuevo conocimiento y la articulación entre los equipos técnicos para el cumplimiento de los objetivos durante la formulación de Planes de ordenación y manejo de cuencas hidrográficas (POMCA). Teniendo como referencia las experiencias vividas durante la realización de este estudio, se puede decir que es fundamental que en el aprestamiento y durante el inicio del diagnóstico, los profesionales realicen reuniones de conceptualización para que los diferentes productos a obtener muestren una participación conjunta desde los diferentes saberes.

\section{Introduction}

Watershed management is a planning process that is constant, methodical and complete, which is executed by the guild that interacts in and with the territory of a watershed, aimed at the use and management of the assets of the same, so as to maintain or restore an appropriate balance between the social and economic use of such resources and the preservation of the structure and physical-biotic function of the watershed [1]. The policy for integrated water resource management (PGIRH) [2] was issued in 2010 by the Ministry of Environment, Housing and Territorial Development, which contains the primary guidelines for the administration and organization of water resources. It should be noted that the PGIRH emphasizes the continuous improvement of territorial planning models related to water resource management [2]. Specifically, it proposes novel guidelines for the formulation of the POMCA, whose purpose is to plan the sustainable use and management of renewable natural resources in order to conserve or re-establish an adequate balance between the socio-economic disposition of such resources and the conservation of the physical-biotic structure of the basin [2].

The Francisco de Paula Santander University (UFPS), the Association of Regional Autonomous Corporations (ASOCAR's) and the North Eastern Frontier Regional Autonomous Corporation (CORPONOR) signed agreement 000036 in 2011, with the intention of making an adjustment to the planning and management of the Pamplonita river basin. The basin located on the eastern mountain range, extending southwest of Norte de Santander, from Pamplona to Puerto Santander, has an area of approximately 140,603 Ha, and approximate length of $115 \mathrm{~km}$, covers the municipalities of Villa del Rosario, Los Patios, Chinácota, Pamplonita, Herrán and Ragonvalia, which are fully included in the basin and the municipalities of Cúcuta, Bochalema, Puerto Santander and Pamplona partially. The importance of elaborating this research did not lie solely in conceiving a pilot project that would implement the provisions of the policy in the hydrographic basins component, but also in providing feedback through the systematization of the exercise and in turn constructing an appropriate conceptual framework and contextualized from a real experience, which can be consulted by other teams that seek the management of other basins in the country in conditions similar to the present exercise, where limitations were found, such as the lack of documentation for the achievement of objectives [2].

In accordance with Decree 1640 of 2012 [3] and based on the Technical Guide for the formulation of watershed management plans [1], this process was carried out in the following stages: preparation, diagnosis, foresight and environmental zoning. In addition, for the development of these stages, a large team of professionals was distributed in the following components: geographic information systems (GIS), water, soil, biotic, socioeconomic, communications, digital atlas, foresight and formulation. In order to prepare it, a review of the literature on the subject was carried out, an evaluation and follow-up of the progress reports submitted by each of the components, an analysis of the conclusions that emerged as a result of the weekly work tables of the technical and administrative team, the application and reading of a format applied during the systematization of the experience and the reading and analysis of the policy [2] and the guide [1]. As a result, a conceptual framework was structured that contains the terms that 
the project professionals considered most important to be managed by the entire team that participated in a watershed management process. These concepts are divided into two groups, one of general basin management terms and the other with very specific terms specific to each component.

\section{Materials and Methods}

\section{Revision of information from secondary sources}

The collection of information consisted of reviewing concepts, theories, regulations and the background of studies on river basin management and management. It is important to clarify that the compilation of information was not only carried out at the beginning of the investigation, but was generated throughout the course of the investigation; with the purpose of clarifying and defining the concepts and techniques for the construction of the body of the investigation and the optimal scope of the objectives outlined. The information was obtained from various sources, such as the UFPS Eduardo Cote Lamus library, databases, web search engines, public institutions such as the Agustín Codazzi Geographic Institute (IGAC) [4], the Institute of Hydrology, Meteorology and Environmental Studies (IDEAM) and CORPONOR.

\section{Recognition of each of the phases required for the construction of the POMCA}

At this stage, a detailed reading and analysis was made of the technical guide [1], which establishes the principles, procedures and knowledge of the stages of environmental readiness, diagnosis, prospective and zoning, and formulation required in the construction of POMCAS. In the recognition of each of the phases, the key terms most frequently used, the processes and the products expected to be obtained were defined.

\section{Follow-up and accompaniment of the different activities carried out during the Pamplonita river development project.}

During the execution of the project, an integral follow-up and accompaniment of each one of the executed activities was carried out, where minutes of the meeting were drawn up in which the different aspects to be dealt with, lessons learned, participants and conclusions were recorded. Some of these activities were: meetings of the technical team in charge of the POMCA of the Pamplonita River, learning transfer workshops, meetings with basin councillors, workshops in charge of the foresight team on vision and structure of scenarios and socialization of progress by the technical team before ASOCARS.

\section{Design, application and reading of a qualitative instrument to obtain information}

An instrument was designed for the collection and evaluation of some concepts and theories applied in basin management processes (Tables I and II). These instruments were then applied to each of the coordinators of the project components, who from their professional perspective carried out the analysis and evaluation of the project. These formats were provided to each member of the technical team in digital and physical format, additionally there was an accompaniment during the process of application and completion of the same. Finally, the information obtained in the applied formats was read and studied in order to achieve the construction and organization of new knowledge in terms of concepts, theories and variables.

\section{Information gathering and critical interpretation}

This stage involved the construction of a logical and coherent conceptual framework that supports a basin management process based on real experience. The following tables refer to the tools used to compile, construct and analyze the general terminology that should be managed by all members participating in basin management processes. 
Table I. Instrument for construction of conceptual framework, specific terms by component.

\section{CONCEPTUAL FRAMEWORK: WATERSHED MANAGEMENT}

1. According to its professional training and to the component to which it is linked within the Pamplonita River Basin Management Adjustment Project, which terms it considers of greater importance to be managed in a common language by all the team that participates in a watershed management process:

Component:

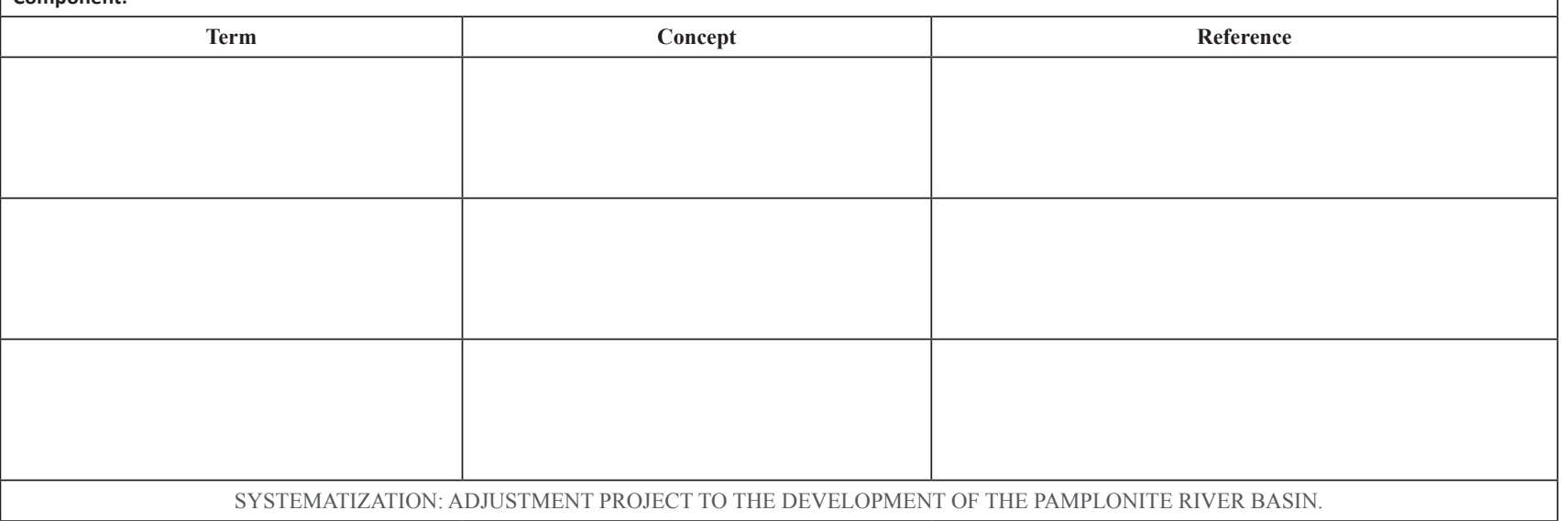

Table II. Conceptual framework, general terms

\begin{tabular}{|c|c|c|c|c|c|c|c|}
\hline \multirow[t]{2}{*}{ Term } & \multirow[t]{2}{*}{ Concept } & \multirow[t]{2}{*}{$\begin{array}{c}\text { Reference Bibliographic } \\
\text { consulted }\end{array}$} & \multirow{2}{*}{$\begin{array}{c}\text { Recommended } \\
\text { bibliographic reference }\end{array}$} & \multicolumn{2}{|c|}{$\begin{array}{l}\text { Considers the term of } \\
\text { great importance }\end{array}$} & \multirow{2}{*}{$\begin{array}{c}\text { If you } \\
\text { answered NO, } \\
\text { for what term } \\
\text { would you } \\
\text { replace it? }\end{array}$} & \multirow{2}{*}{$\begin{array}{c}\text { Recommended } \\
\text { Bibliographic } \\
\text { Reference }\end{array}$} \\
\hline & & & & Yes & No & & \\
\hline POMCA & $\begin{array}{l}\text { Instrument for the planning } \\
\text { of the coordinated use of } \\
\text { land, water, flora and fauna, } \\
\text { and the management of the } \\
\text { basin in the perspective of } \\
\text { maintaining the balance } \\
\text { between the social and } \\
\text { economic use of these } \\
\text { resources. }\end{array}$ & $\begin{array}{l}\text { order } 1640 \text { / } 2012 \text { (Art. } \\
18 \text { ) }\end{array}$ & & & & & \\
\hline $\begin{array}{l}\text { Sustainable } \\
\text { development }\end{array}$ & $\begin{array}{l}\text { It is development that } \\
\text { meets the needs of the } \\
\text { present generation without } \\
\text { compromising the ability of } \\
\text { future generations to meet } \\
\text { their own needs. }\end{array}$ & $\begin{array}{l}\text { "Our Common Future", } \\
\text { prepared by the UN } \\
\text { World Commission } \\
\text { on Environment and } \\
\text { Development - } 1987\end{array}$ & & & & & \\
\hline Hydrographic Basin & $\begin{array}{l}\text { An area of surface water or } \\
\text { groundwater discharging } \\
\text { into a natural hydrographic } \\
\text { network with one or more } \\
\text { natural streams, continuous } \\
\text { or intermittent, flowing } \\
\text { into a major stream which, } \\
\text { in turn, may flow into a } \\
\text { main river, a natural water } \\
\text { reservoir, a reservoir or } \\
\text { directly into the sea. }\end{array}$ & $\begin{array}{l}\text { Art. } 3 \text { del order } 1640 \\
\text { de } 2012\end{array}$ & & & & & \\
\hline $\begin{array}{l}\text { Management of river } \\
\text { basins }\end{array}$ & $\begin{array}{l}\text { Permanent, systematic, } \\
\text { predictive and integral } \\
\text { planning process carried } \\
\text { out by the set of actors that } \\
\text { interact in and with the } \\
\text { territory of a basin, leading } \\
\text { to the use and management } \\
\text { of its natural resources, in } \\
\text { such a way as to maintain } \\
\text { or re-establish an adequate } \\
\text { balance between the } \\
\text { social and economic use } \\
\text { of these resources and } \\
\text { the conservation of the } \\
\text { structure and the physical } \\
\text { and biotic function of the } \\
\text { basin. }\end{array}$ & $\begin{array}{l}\text { IDEAM. (2013). A Guide } \\
\text { to Watershed Planning } \\
\text { and Management in } \\
\text { Colombia }\end{array}$ & & & & & \\
\hline
\end{tabular}




\section{Results and analysis}

General conceptual framework for basin planning based on the systematisation of the Pamplonita river basin planning experience. Transversal concepts and land use planning

The design of the conceptual framework was carried out with the contribution of the most significant concepts of each discipline in the exercise of the construction of a river basin management. In this first part we present the basic definitions associated with the terms that the project professionals considered of greatest importance to be managed in a common language by all the team that participates in a process of watershed management and key terms used more frequently according to the review of the literature. In view of the above, the general concepts chosen by the consulting team were:

\section{Ambience}

It is the set of physical, biological, social and cultural interactions, established or not, between humans and other living beings and all the components of the environment in which they operate, whether these elements are natural, transformed or created by man [5].

\section{Communication}

It is the structuring axis of the standard of participation in river basins and of the technique suggested to achieve it [1].

\section{Hydrographic basin}

A catchment area or hydrographic basin refers to the area of surface water or groundwater flowing into a natural hydrographic network with one or more natural streams, of constant or sporadic flow, which converge into a larger stream which, in turn, may flow into a main river, a natural water reservoir, a reservoir or directly into the sea [3].

\section{Sustainable development}

Development that offsets the needs of the present generation without compromising the ability of future generations to meet their own needs [6].

\section{Environmental education}

Procedure that grants the individual to understand the links of interdependence with his environment, from the reflexive and critical perception of his biophysical, social, political, economic and cultural reality, so that, from the appropriation of the concrete reality, behaviors of respect for the environment can be generated in him and in his community [5].

\section{Territorial planning}

Group of political-administrative practices and physical planning designed to have efficient mechanisms that lead to the development of the territory and the control of the use, transformation and occupation of space [7].

\section{POMCA}

Instrument for the planning of the orderly use of resources and the management of the basin perceived as the development of works and treatments aimed at maintaining the balance between the social and economic use of such resources and the conservation of the physical-biotic structure of the basin and specifically of the water resource [3].

\section{Systematization}

The intention of the systematization of experiences in watershed management is the capitalization of practices and results achieved in order to form a basis or starting point for the feedback of the decisionmaking phases, which are reflected in public policies, plans, programs, projects and regulations [1].

\section{Systematization of experiences}

The systematization of experiences is an evaluation and reconstruction of an experience, its actors, the activities carried out and the environment in which they took place [8].

\section{Systematization object}

It is the delimitation of the practices and lessons that we hope to systematize. It requires asking questions such as: What experience are we going to systematize? Will we systematize all the experiences, or only one in particular? Will we cover only a certain period or stage? With what criteria will we select the 
experience and what value will we give to each one of them? [9].

\section{Systematization axis}

It is the one that facilitates establishing the course of the systematization. The same experience can be systematized from several axes, according to interest or demand. It must be formulated according to the objective and object of systematization [9].

\section{Lessons learned}

They are defined as the knowledge acquired through reflection on an experience or a set of experiences. They recognize success factors, as well as deficiencies or weaknesses in a process. They must be: adaptable, authentic and representative [10].

Conceptual framework from the perspective of each of the components that participated in the planning process of the pilot project for Colombia of the Pamplonita river basin.

This conceptual framework was structured from the experience of the team of professionals who participated in the adjustment to the POMCA of the Pamplonita River. Each professional, based on their training, knowledge and experience, made a significant contribution to the construction of the conceptual framework of each component. Having as a reference the experiences lived during the project, it can be said that it is fundamental that in the preparation and during the beginning of the diagnosis the professionals carry out conceptualization meetings so that the different products to obtain show a joint participation from the different knowledges.

In figure 1 we see that the construction of the concept of management is done from the understanding of the environment as the proper relations between society, nature and culture, and considering the basin as an environmental system. This principle defines that management is carried out on a dynamic system where, depending on the type of relationship (conservation or degradation), the system can be preserved or lose its equilibrium. From this point of view, each of the professionals in charge of obtaining information for planning used the concepts of their own knowledge and shared scientific information to diagnose the territory, define the problems and supply, and formulate a sustainable basin model.

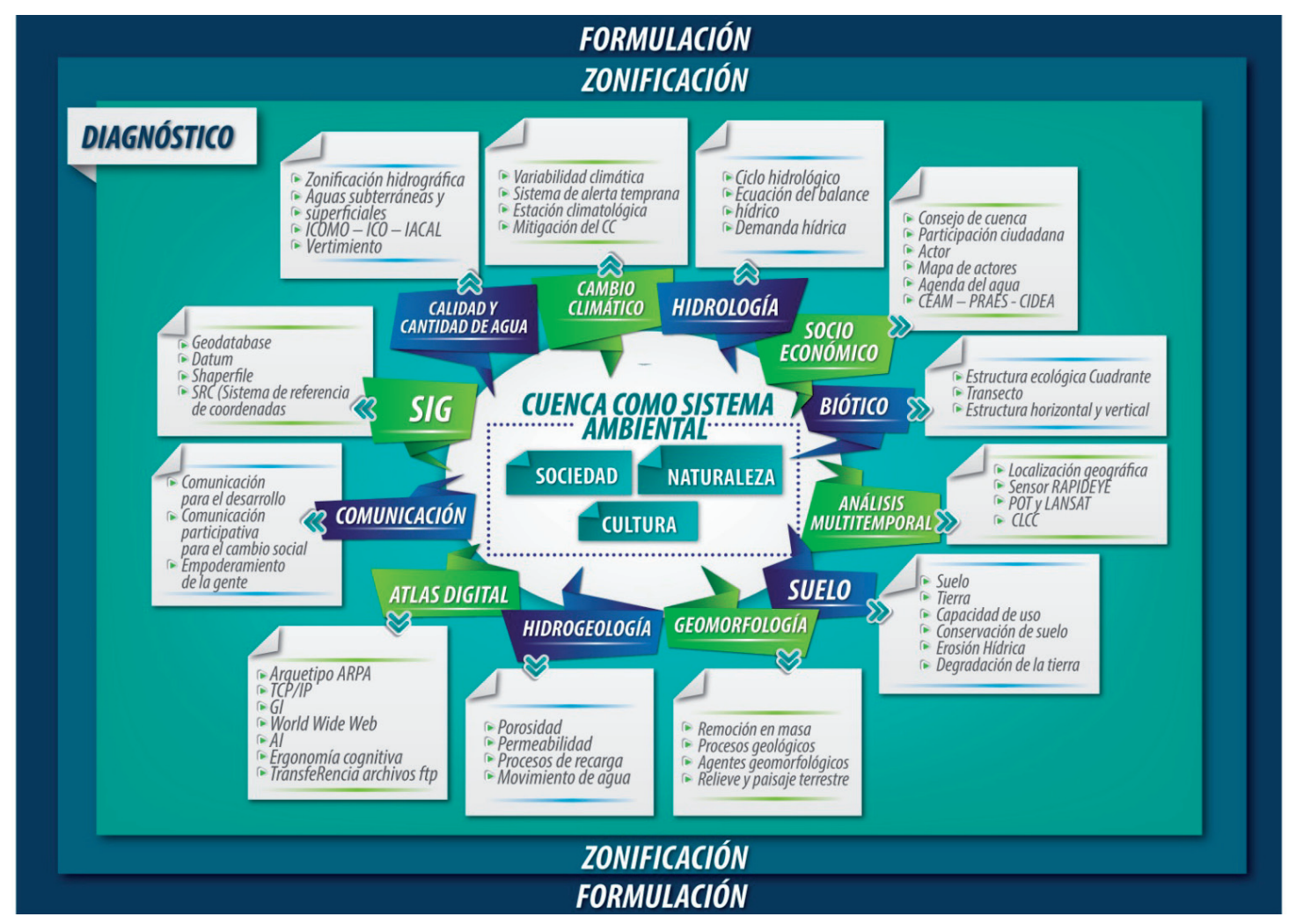

Figure 1. Basin management concepts based on the systematization of the pilot project for Colombia of the Pamplonita river basin. 


\section{Conceptual framework of the water component}

The existence and preservation of the environment in which we live depends indisputably on water, as do the processes that take place in it. Studies in this component include: hydrology and climate change.

\section{Hydrology}

The main concepts to be taken into account in this component can be appreciated in figure 2 . In the hydrological aspect, fundamentally, the superficial water supply and its relation with the water demand is quantified. The surface water supply is obtained from the different components of the hydrological cycle analysed at basin and sub-basin level (25 subbasins in the Pamplonita river basin), for annual and monthly time scales. In the case of water demand, the different activities that use the resource within the basin are considered, and within the framework of the ordering of the basin, the study focuses on the concessions for the use of water granted by the corresponding Regional Autonomous Corporation. Based on the general inventory of surface waters, it is necessary to estimate three demands: total or general demand for the water resource that gave a total of 9097 litres per second for 4024 users afferent to the Pamplonita river basin, of which $34 \%$ of the flow granted by regulation, $41 \%$ of the flow surveyed and $25 \%$ of the flow granted by concessions stand out. It is important to point out that, in general, the conceptual framework approaches follow the guidelines presented by IDEAM in its document [11].

\section{Climate Change}

It is the modification of the state of the identifiable climate in the oscillations of the average value and/ or in the variability of its properties, which lasts for long periods of time, generally decades or longer periods [12]. The main concepts to be taken into account in this component can be seen in figure 3 .

For the analysis of climate change in the Pamplonita river basin, 60 IDEAM climatological stations were selected, an entity that states that the department of Norte de Santander is one of those that has felt the increase in temperature the most and is one of the most vulnerable in the future. The statistical

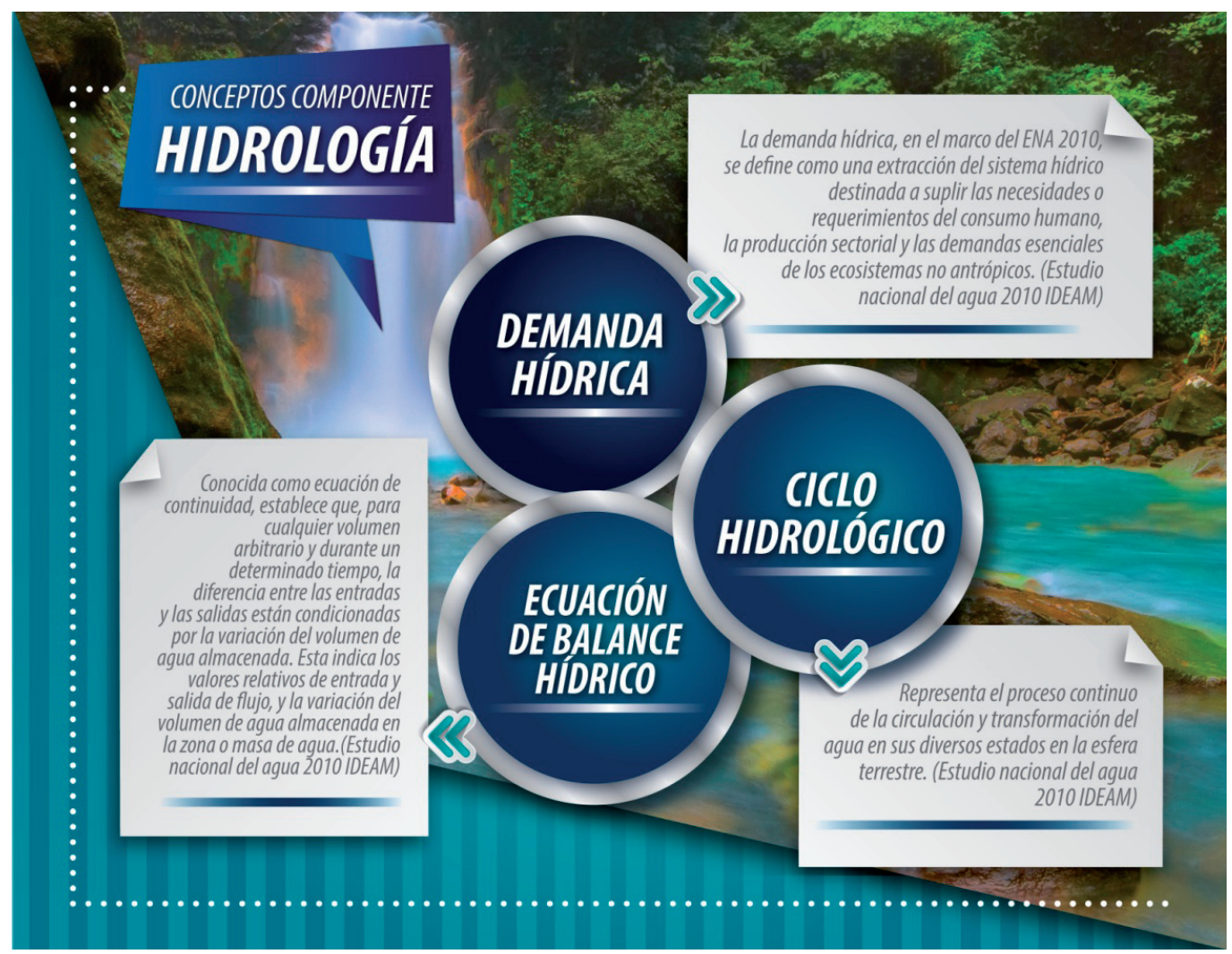

Figure 2. Concepts hydrology component from the systematization of the pilot project for Colombia of the Pamplonita river basin. 
analysis of trends shows that the average monthly temperature has indeed increased over the last thirty years and the average annual rainfall is distributed between areas of increase and decrease. The climate changes in scales of time and space, these fluctuations (climate variability) as such occur in the values of climate variables such as temperature and precipitation, a typical example of inter-annual climate variability corresponds to phenomena within the ENSO cycle, southern oscillation (El Niño, warm phase - La Niña, cold phase). Climate variability and change are considered to have a direct and constantly interacting relationship associated with changes in radioactive forcing, which have their origin in the anthropogenic greenhouse effect [13]. As a starting point in the analysis of the climatic variability associated with the ENSO cycle and its El Niño and La Niña phases in the Pamplonita basin, the climatological averages of the variables Average Precipitation and Average Temperature in the 1981-2010 interval were reviewed. In general, measures to adapt to variability and climate change are based on reducing vulnerability. In addition, the early warning system refers to the ability to provide timely information on the occurrence of an extreme climate event, based on a group of people trained for this purpose, a series of computer equipment and a network of meteorological stations properly installed in the territory whose readings are detected, analyzed, transmitted and disseminated efficiently among SAT users [13].

\section{Conceptual framework of the soil component}

The conceptual framework of any soil research in terms of watershed management should be developed from the aspects recommended below (Figure 4).

In figure 4, we can conclude that the earth is the terrestrial environment that occupies a geographical space and where the natural components of the ecosystem (soil, water, air, flora and fauna) are found together with man; In turn, soil is a natural three-dimensional, three-phase (solid, liquid and gaseous) and biodynamic body, composed of a mineral fraction and an organic fraction, located on the surface of the earth's crust at the interface of interaction of the physical elements that make up

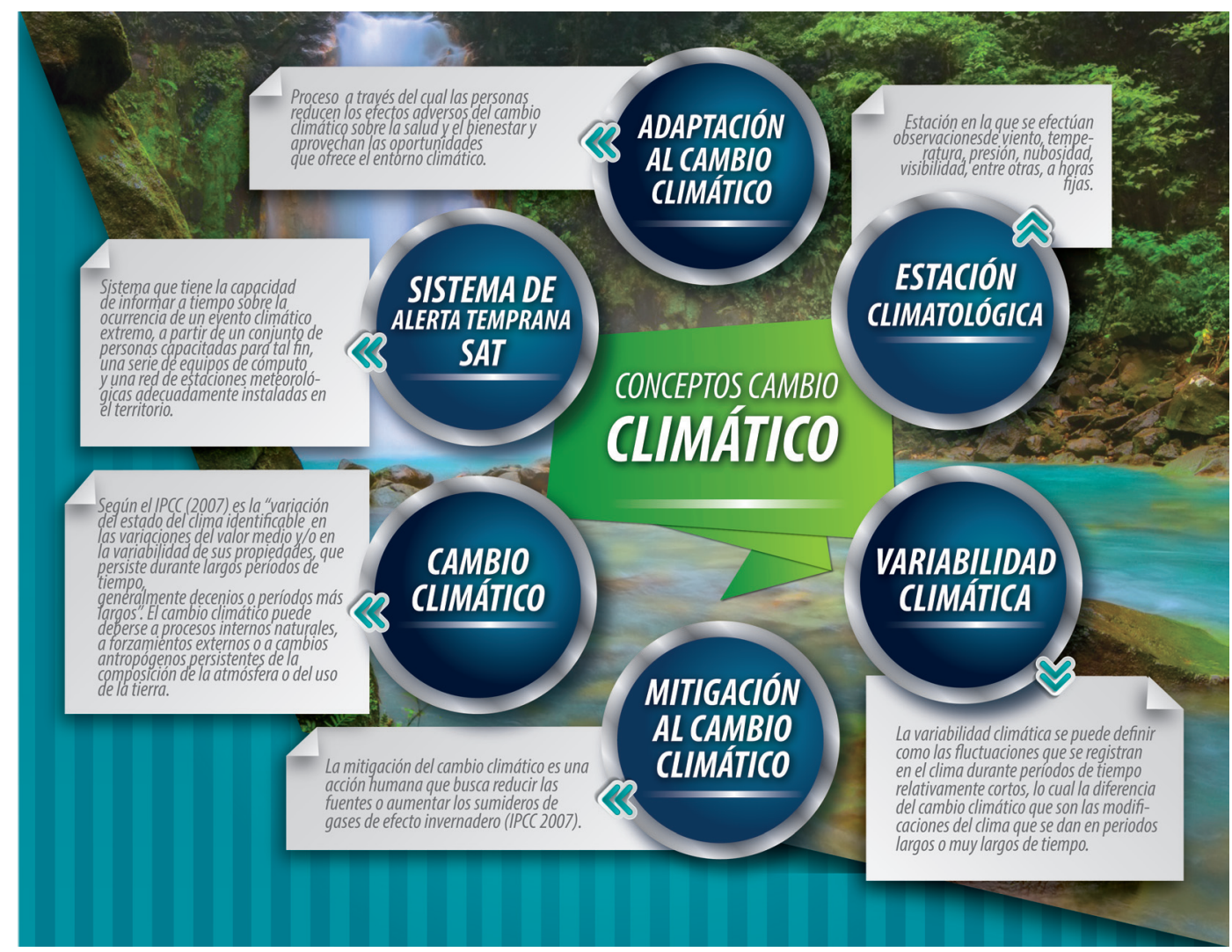

Figura 3. Concepts component climate change from the systematization of the pilot project for Colombia of the Pamplonita river basin. 
our planet, with properties and attributes that allow it to be the natural substratum with the capacity to sustain life in terrestrial environments [1]. The classification by use capacity is the assignment of classes, subclasses and management groups that are given to the different cartographic units defined in the study of soils for a practical use according to the capacity to produce crops and/or pastures; while the agrological classification is based on the potentiality of the soils and their limitations, as well as on the management difficulties. The soils found in the study area were gathered in 7 agrological classes from 2 to 8,24 subclasses and 33 management groups were created. Classes II, III and IV have as vocation the agricultural use, in class $\mathrm{V}$ are grouped flat topography soils with fertility limitations, classes VI and VII are suitable for pasture and finally class VIII has no agricultural aptitude, only allows the development of wildlife. In general, the diagnostic study carried out by the professional team of the soil component detected that this resource is undergoing an intense process of degradation.

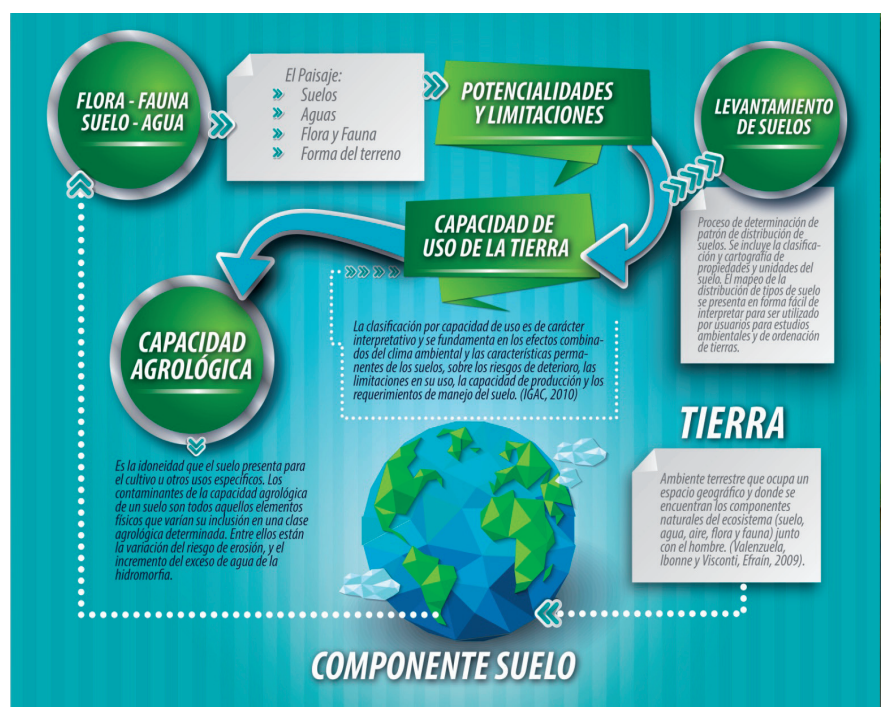

Figure 4. Component soil concepts from the systematization of the pilot project for Colombia of the Pamplonita river basin.

\section{Conceptual framework of the biotic component}

The proposal shown in figure 5 derives from the revision, consolidation and unification of concepts used by the biotic component [16].

The support base of the structure and functionality of the basin is developed based on the characterization and spatialization of the main ecological structure, which requires the participation of all the biophysical and socioeconomic components in the definition of spatial units that ensure the sustainability of natural resources to meet their ecosystem services of provision, regulation, habitat and support. The main ecological structure is an input of environmental zoning, to propose projects of preservation, conservation and restoration of biodiversity in those natural areas of the Basin where the service provided is in critical situation and its tendency of deterioration in the medium and long term is unrecoverable. Biodiversity and ecosystem services provide provisioning, regulation, support and cultural services. The consolidated secondary information records for the Pamplonita River Basin, a total of 1473 species of flora and 827 species of fauna; 207 families of flora and 152 families of fauna. Compared to the 2010 POMCHA, which recorded a total of 559 species of flora and 552 species of fauna, and 141 families of flora and 118 families of fauna. This is evidence of the process of updating the Basin's biodiversity information.

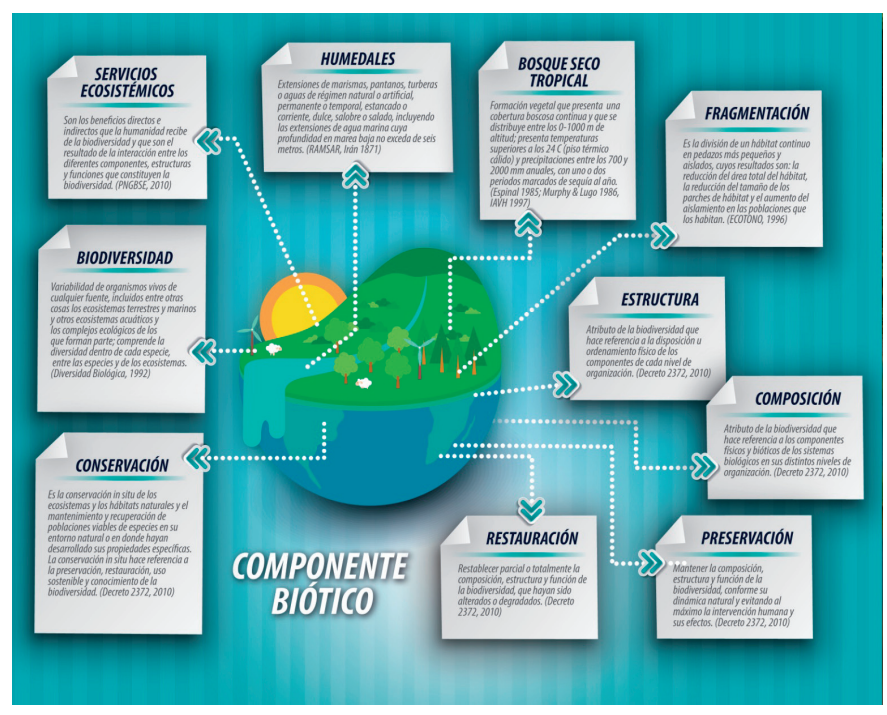

Figure 5. Component soil concepts from the systematization of the pilot project for Colombia of the Pamplonita river basin.

\section{Conceptual framework of the socio-economic component}

Citizen participation is a tool that guarantees the respect and fulfillment of rights, the practice of responsibilities, virtues, attitudes and civic behavior; and promotes the belonging and equality of persons and groups with a given community [17]. The team of the present component based the profile of the 
participation strategy on this theoretical postulate and proposed the development of actions aimed at exercising the "active citizenship" of each of the actors of the basin so as to empower their faculties and skills to participate actively in the adjustment, implementation and monitoring of the POMCA. The minimum guidelines for the identification of possible actors were carried out at the level of each of the municipalities and at the level of the entire Pamplonita River Basin. The actors in the basin have different positions, interests and needs, mainly according to their economic activities, which is why they were classified into four groups: productive, civil society, institutional and academic.

It is important to highlight that the basin councillor has allowed the rescue of the will of the civil, institutional, academic and productive sector together with the emergency generated by the quality and availability of water, the environmental situation and infrastructure that has been present throughout the territory that makes up the basin. zoning, where future scenarios will be designed for the coordinated and sustainable use of the soil, water, flora and fauna present in the Basin.

Prospective is a methodology that essentially seeks to analyze the scientific, technical, economic, political, social and cultural antecedents that precipitate the development and improvement of the modern world and the prediction of some situations that may manifest [17]. Its main objective is to point out the alternatives that the Pamplonita River basin has for its future with clear management and planning processes, identifying the different scenarios in which it could find itself in twenty years, in terms of its hydrological, biotic, soil and socioeconomic components, choosing from these future options the most convenient to anticipate strategic decisions from the present. Foresight encourages us to question the different conflicts, challenges and competencies of society, as well as to visualize the future. At present, the studies of the future from the deterministic approach that try to predict the future

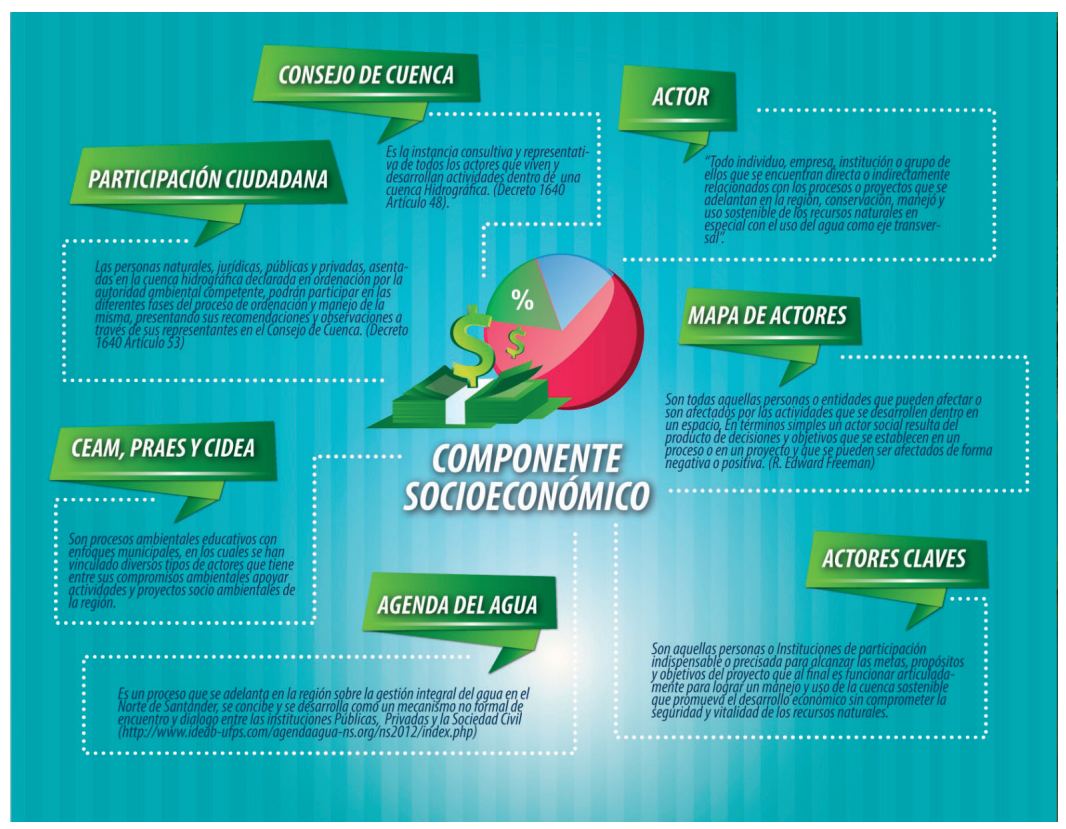

Figure 6. Socio-economic component concepts based on the systematization of the Pamplonita river basin pilot project for Colombia.

\section{Conceptual framework of the prospective component}

The main concepts to be taken into account in this component can be seen in figure 7. Decree 1640 of 2012 directly relates foresight to environmental are known as "forecasting". The volunteer school describes a basic content of past, present and future [18]. It starts from understanding that in the past are the learnings, results of the mistakes and successes of the decisions made, and that memory is necessary as a valuable input to explain what we are in the 


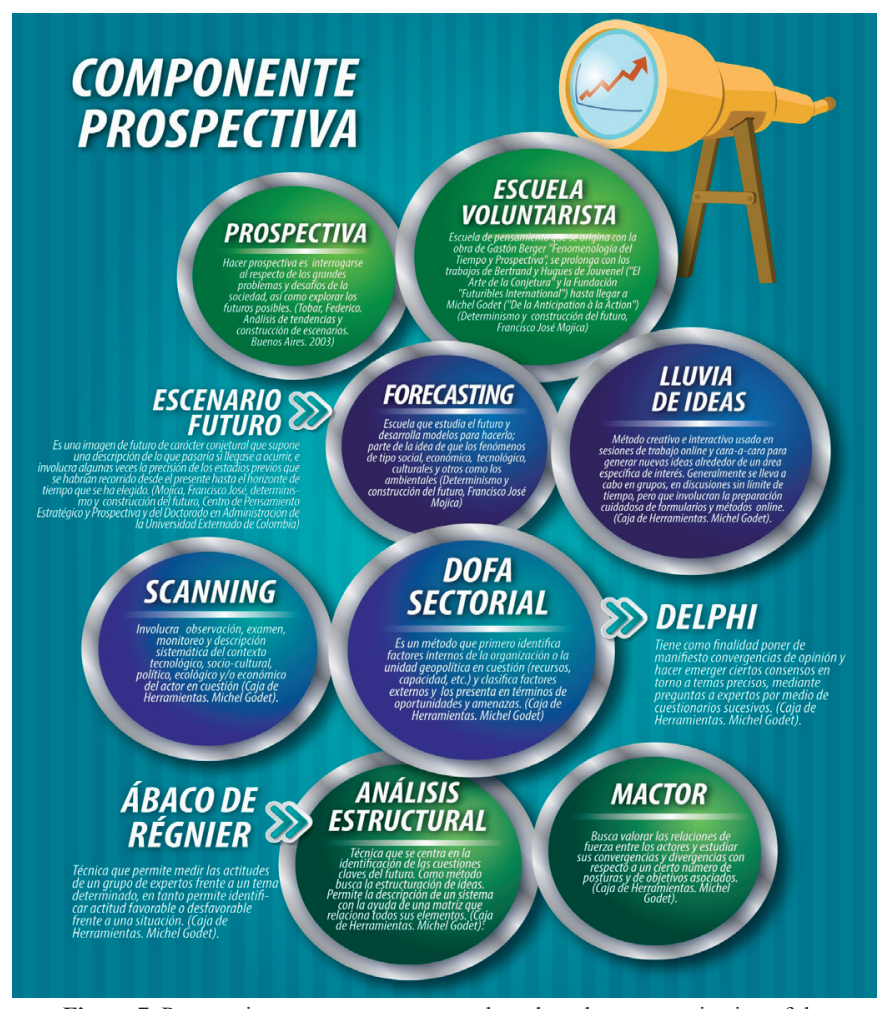

Figure 7. Prospective component concepts based on the systematization of the Pamplonita river basin pilot project for Colombia.

present; in turn, this present becomes the opportunity for management and decision making. Decisions should therefore contain loads of high information that give the study of the future. Structural analysis provides a detailed definition of the system based on a matrix that links all its elements and contemplates qualitative factors. It has the advantages of allowing qualitative diagnosis, collective reasoning and encouraging criticism of various aspects of the system [19]. In the case of the work carried out during the adjustment to the POMCA of the Pamplonita river, the relevance and importance of each one was qualified using the "Abacus of François Régnier" technique, which consists of a scale of colours, based on the polychrome of the traffic light.

\section{Component conceptual framework SIG}

The following is a set of important terms when discussing the graphic representation of the territory (figure 8). The GIS is a specific tool for the use of spatial information and its properties. A GIS has the capacity to examine and delve into three aspects: metric, topological and attributive. [20]. Among their multiple advantages, it is worth mentioning that they facilitate the processing of geographic information using fewer resources and time than in previous years, and they promote the creation of novel alternatives to solve diverse inconveniences that may arise (maps, data sheets, etc.). The digitization of geographic information required the support and guidance of each of the contractors in charge of their respective thematic areas to adjust the plan, in order to finally structure the cartographic and alphanumeric information created and acquired in a geodatabase.

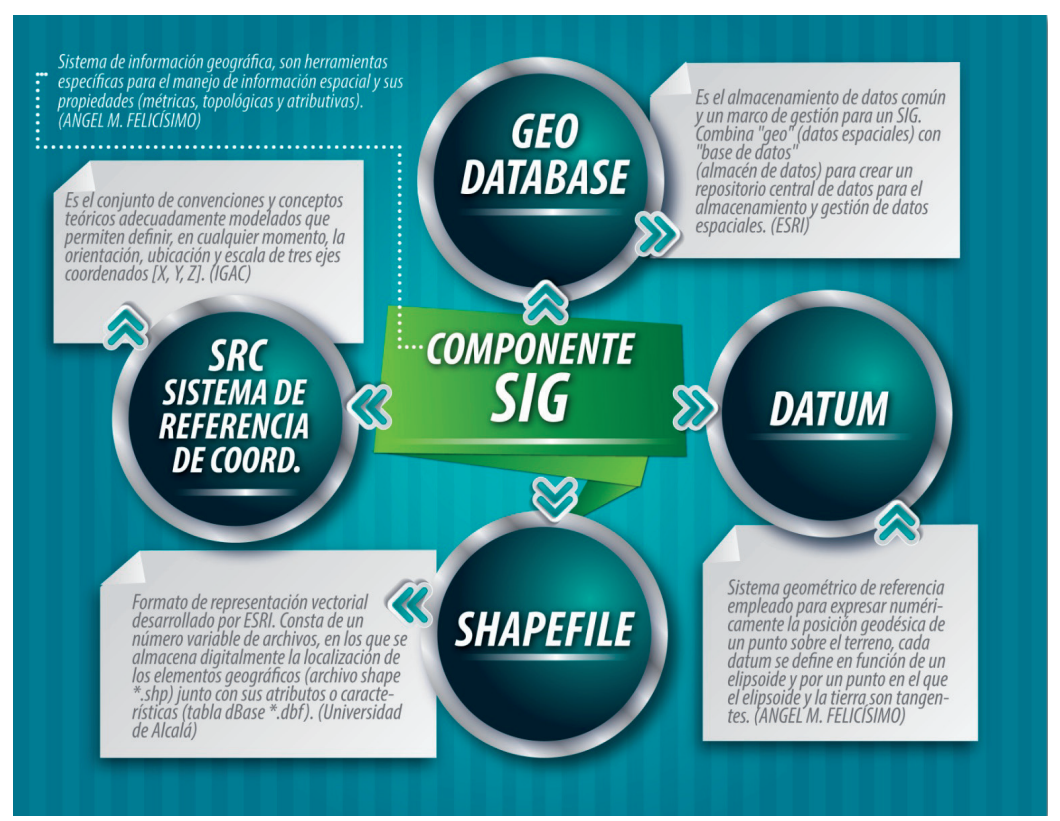

Figure 8. GIS component concepts based on the systematization of the pilot project for Colombia of the Pamplonita river basin. 


\section{Conclusions}

A clear conceptual framework allows the research to be guided, provides a review to decipher and understand the results of the study and facilitates the production of new knowledge and the articulation between the technical teams for the fulfillment of the objectives during the formulation of the River Basin Development and Management Plans (POMCA). Having as reference the experiences lived during the realization of this study, it can be said that it is fundamental that in the preparation and during the beginning of the diagnosis the professionals carry out conceptualization meetings, so that the different products to obtain show a joint participation from the different knowledges.

\section{Acknowledgements}

The authors express their gratitude to the working teams of the Association of Regional Autonomous Corporations and Sustainable Development ASOCARS, the Regional Autonomous Corporation of the North Eastern Border CORPONOR, the embassy of the Kingdom of the Netherlands, the Basin Council, the UFPS, the Institute of Environmental Studies IDEAB and the University of Pamplona for their administrative, financial and technical collaboration during the execution of the project. To the graphic designer Jeny Carolina Vargas García for her contribution to the organization and artistic and visual approach of the final pieces of this research.

\section{References}

[1] Ministerio de Ambiente y Desarrollo Sostenible - IDEAM. "Guía técnica para la formulación de los planes de ordenación y manejo de cuencas Hidrográficas POMCAS”. Bogotá D.C, 2014.

[2] Ministerio de Ambiente, Vivienda y Desarrollo Sostenible. Política Nacional para la Gestión Integral del Recurso Hídrico - PNGIRH, 2010

[3] Ministerio de Ambiente, vivienda y Desarrollo Sostenible. Decreto 1640. Bogotá D.C, 2012

[4] Ministerio de Ambiente Vivienda y Desarrollo,
Territorial - IGAC, Instituto Geográfico Agustín Codazzi. Bogotá D.C, 2010

[5] Política Nacional de Educación Ambiental. SINA, 2002

[6] G.H. Brundtland. "Nuestro Futuro Común". Comisión Mundial para el Medio Ambiente y el Desarrollo de la ONU. 1987

[7] Congreso de la República. Ley 388, 1997

[8] Citado en la Guía de Sistematización de experiencias. Haciendo memoria de las Redes Sociales de Apoyo (RSA), 2009.

[9] Guía Metodológica de Sistematización Programa Especial para la Seguridad Alimentaria - PESA - y la Organización de las Naciones Unidas para la Alimentación y la Agricultura FAO, 2004. Disponible en: http:// www.pesacentroamerica.org/biblioteca/guia_ sistematizacion.pdf

[10] Banco Interamericano de Desarrollo -BID, 2008

[11] Estudio nacional del agua. ENA, 2010

[12] Grupo intergubernamental de expertos sobre el cambio climático-IPCC. Ginebra, Suiza. 2007

[13] D. Alzate. Señales de cambio y de variabilidad climática en las Cuencas de los Ríos Zulia y Pamplonita e identificación de medidas de adaptación potenciales. Tesis de Maestría, Magíster en Ingeniería Ambiental. Universidad de Pamplona. Pamplona. 2013

[14] I. Valenzuela y E. Visconti. Efecto del uso y manejo sobre la respiración edáfica y biomasa microbial de un suelo del distrito de riego del río Zulia

[15] Ministerio de Ambiente, vivienda y Desarrollo Sostenible. Decreto 2372. Bogotá D.C, 2010

[16] M. Masbernat, N. Carmona y G. Erika. "La participación local: realidad y desafío". Estudios Sociales, Corporación de Promoción Universitaria. pp. 167-204, 1996. Chile 
[17] F. Tobar. “Análisis de tendencias y construcción de escenarios". Buenos Aires. 2003

[18] F. Mojica. "Determinismo y construcción de futuro". Centro de pensamiento estratégico $y$ prospectivo. Universidad externado de Colombia, 1991

[19] M. Godet. "La caja de herramientas de la prospectiva estratégica”. España, 2000.

[20] A. Felicísimo. Sistemas de información geográfica. Universidad de Extremadura. España. 